\title{
The Effect of Dietary Salinomycin Supplementation on Insulin Secretory Response to Feeding in Fattening Steers
}

\author{
Yoshiaki Terashima, Tadashi Kuroyanagi, Yutaka \\ MiYakoshi, Yoshinori FuKuda and Yo Kondo \\ Faculty of Animal Science, Kitasato University, \\ Towada-shi 034
}

(Received August 15, 1989)

\begin{abstract}
The effect of dietary salinomycin supplementation $(200 \mathrm{mg} / \mathrm{head} /$ day $)$ on insulin secretory response to feeding was investigated using 16 Japanese shorthorn steers (initial age, approxi. 314 days; average initial weight, $329 \mathrm{~kg}$ ). Four steers were allotted to each of four treatments providing either a low $(0.6 \%$ concentrate of body weight) or a high (1.8\% concentrate of body weight) concentrate diet supplemented with or without salinomycin in a $2 \times 2$ factorial arrangement of treatments. All groups were provided alfalfa hay ad libitum throughout the fattening period of 10 months. Dietary salinomycin did not influence the rates of gain in fattening steers. There was no significant salinomycin $\times$ concentrate level interaction on feed conversion. Steers fed the salinomycin diet converted $(\mathrm{P}<0.10)$ the feed to gain $14 \%$ more efficiently than the unsupplemented diet-fed steers due to the lower rates of feed intake. Dietary salinomycin increased ruminal molar percentages of propionate after feeding and decreased ruminal butyrate proportions, but did not influence ruminal acetate proportions. There was no significant difference in plasma glucose concentrations at any time after feeding between dietary salinomycin treatments. Plasma insulin concentrations in steers fed the salinomycin diet were higher than those of the unsupplemented diet-fed steers at 4-6 hrs after feeding in the high concentrate diet. Dietary salinomycin also increased $(P<0.05)$ the plasma insulin area over $360 \mathrm{~min}$ after feeding across the concentrate level. These results indicated that dietary salinomycin stimulated insulin secretory response to feeding in fattening steers. This may partly account for improved feed conversion of steers fed the salinomycin diet.
\end{abstract}

Jpn. J. Zootech. Sci., 61 (3) : 271-276, 1990

Key words : dietary salinomycin, plasma insulin, fattening steer

Carboxylic polyether ionophores have been shown to increase feed efficiency in beef cattle $^{1)}$. Salinomycin, one of the ionophores, produced by streptomyces albus has been used to improve steer performance in the pasture and in the feedlot ${ }^{2-4)}$. Although many experiments indicate that dietary ionophore alters ruminal metabolism, especially in inducing an increase in propionate production ${ }^{2,5,6)}$, several studies suggest an effect of ionophores on metabolism in ruminants independent of alterations in ruminal microbial metabolism ${ }^{3,7,8)}$. However, this mode of action of ionophores is still obscure.

Plasma insulin concentrations increase after feeding in nonruminant and ruminant animals. Postprandial increase in plasma insulin may play an important role in the efficiency of 
performance of beef cattles, because insulin has the potency to stimulate anabolic action in the body ${ }^{9)}$. Intravenous administration of monensin ionophore increased plasma insulin concentration suggesting that an increase in plasma insulin could be mediated through the direct effects of monensin ${ }^{8)}$. However, the relationship between dietary salinomycin supplementation and postprandial increase in plasma insulin has not been explained. The objective of the present experiment was to determine the effect of dietary salinomycin supplementation on insulin secretory response to feeding in fattening steers fed either a low or a high concentrate diet.

\section{Materials and Methods}

Sixteen Japanese shorthorn steers (intial age, approxi. 314 days; average initial weight, $329 \mathrm{~kg}$ ) were divided randomly into four groups of four steers. Before the start of the fattening experiment, all steers were adapted to eating from individual electronic headgates. They were initially subjected to the ad libitum feeding of alfalfa hay containing $18.1 \%$ crude protein, $1.9 \%$ ether extract, $23.7 \%$ crude fiber, $40.9 \% \mathrm{NFE}$ and $15.4 \%$ crude ash on dry matter basis. Subsequently, two groups were adapted gradually to a low concentrate diet $(0.6 \%$ concentrate of body weight) and a high concentrate diet ( $1.8 \%$ concentrate of body weight) while feeding of alfalfa hay was contained ad libitum. The concentrate diet consisting mainly of corn and soybean meal contained $12.1 \%$ crude protein, $4.2 \%$ ether extract, $4.5 \%$ crude fiber, $76.2 \% \mathrm{NFE}$ and $3.0 \%$ crude ash, respectively. At the start of the fattening experiment, one group each of diet-fed steers was fed the respective diet supplemented with salinomycin, which was added to the concentrate diet to provide a level of $200 \mathrm{mg} / \mathrm{head} /$ day throughout the fattening period of 10 months. All steers were weighed at 4-week intervals and were provided the corresponding amount of concentrate diet to their body weights for 4 consec- utive weeks during the whole fattening period. Actural feed intake was estimated by measuring the residual feed.

Rumen fluid and blood samples were duplicately obtained at approximately 240 and 360 days after the start of the fattening experiment. All steers were adapted to a $2 \mathrm{hr}$-feeding period for 4 days prior to the experimental day for sampling. On the experimental day, rumen fluid and blood samples were taken at 0 , $1,2,3,4$ and $6 \mathrm{hrs}$ after the initiation of feeding via a stomach tube inserted orally to the rumen and via the jugular vein by venipuncture, respectively. Individual volatile fatty acid (VFA) concentrations in the rumen fluid were measured via gas chromatography as described previously ${ }^{10}$. Plasma glucose and insulin concentrations were determined by a glucose analyzer (Model GLU-1, Toa Electronics Ltd., Tokyo) and a radioimmunoassay kit (Eiken Chemical Co., Ltd., Tokyo), respectively. The insulin area, which is the area beneath the curve for insulin concentration, was calculated over 360 min after feeding ${ }^{10)}$.

All data were analyzed as a $2 \times 2$ factorial design experiment. Data for feed intake, rates of gain and feed conversion were statistically analyzed by a two-way layout design of variance. Analysis of variance was also carried out for plasma glucose and insulin concentrations and for ruminal individual VFA proportion to compare the treatment effect each time after feeding. In the event of a significant interaction between salinomycin supplementation and concentrate level in the diet, the effect of salinomycin within each concentrate level was tested using the $\mathrm{F}$-test.

\section{Results and Discussion}

The data for feed intake, the rate of gain and feed conversion during the whole fattening period are show in Table 1. Average daily feed intake was $8.0 \mathrm{~kg}$ of alfalfa hay and $2.3 \mathrm{~kg}$ of concentrate in the low concentrate diet-fed group, and was 7.5 and $4.4 \mathrm{~kg}$ in the high 
Table 1. Main effects of dietary salinomycin and concentrate level on feed intake, rate of gain and feed conversion in fattening steers

\begin{tabular}{lcccccc}
\hline \hline & \multicolumn{2}{c}{ Salinomycin $(\mathrm{mg} /$ day)" } & & \multicolumn{2}{c}{ Concentrate level } & \\
\cline { 2 - 3 } & 0 & 200 & & Low & High & SD $^{21}$ \\
\hline $\begin{array}{l}\text { Feed intake } \\
\text { (kg/day, dry matter) }\end{array}$ & $11.7^{\mathrm{c}}$ & $10.4^{\mathrm{d}}$ & & $10.3^{\mathrm{b}}$ & $11.9^{\mathrm{a}}$ & 1.2 \\
Rate of gain (kg/day) & 0.98 & 1.01 & & 0.98 & 1.01 & 0.09 \\
Feed conversion & $12.1^{\mathrm{c}}$ & $10.4^{\mathrm{d}}$ & & 10.5 & 12.0 & 1.7 \\
\hline
\end{tabular}

Each value represents a mean of 8 animals.

Mean values in the same column with unlike superscripts differ significantly ( $a, b P<0.05 ; c . d P<0.10$ ).

"See text. 2) Standard deviation.

concentrate diet-fed group, respectively. A significant interaction of salinomycin $\times$ concentrate level was found on the feed intake. Dietary salimomycin decreased $(\mathrm{P}<0.05)$ feed intake in the high concentrate diet, but did not affect the low concentrate diet. Dietary salinomycin slightly increased the rates of gain across concentrate levels, but not significantly. There was no salinomycin $\times$ concentrate level interaction on feed conversion. Dietary salinomycin improved $(\mathrm{P}<0.10)$ feed conversion across concentrate levels. Higher feed intake was observed in the high concentrate diet-fed steers compared to those of the low concentrate diet-fed steers. No significant higher feed conversion was obtained in the high concentrate diet-fed steers.

Rates of gain have been reported to increase in grazing steers, when dietary salinomycin was provided ${ }^{2}$. Feed efficiency in beef cattle fed a concentrate diet was improved by the supplementation of dietary salinomycin, though rates of gain were not affected ${ }^{2,3}$. These results suggest that performance response of beef cattle to dietary salinomycin may be influenced by several factors such as level of ionophores, and energy content of the diet. The present experiment confirmed that dietary salinomycin improved the performance of steers across concentrate level in the diet.

When the main effect of dietary salinomycin on individual VFA proportion was found to be significant after feeding, there was no significant interaction of dietary salinomycin and concentrate level. The concentrate level in the diet did not affect the ruminal molar percentage of individual VFA after feeding (Table 2). Ruminal molar percentages of propionate in steers fed the salinomycin diet were higher at 2-6 hrs after feeding than those of the no salinomycin diet-fed steers. Dietary salinomycin did not affect ruminal acetate proportions across concentrate levels. Significant lower proportions of butyrate were observed at 1-6 hrs feeding in salinomycin supplemented diet-fed steers compared to those of the unsupplemented diet-fed steers. Thus, dietary salinomycin tended to decrease the ratio of acetate to propionate after feeding across concentrate levels in the diet.

Many experiments indicated that the ionophores stimulate propionate production and decrease acetate and butyrate production ${ }^{5,6,11}$. Some studies demonstrated that salinomycin supplementation did not influence molar proportion of VFA in the rumen fluid $^{3,4}$. These discrepancies may be due to many factors as discussed in other reports ${ }^{1,4)}$.

Plasma glucose levels slightly decreased by 2 hrs after feeding in all groups, then recovered to the initial values (Table 3 ). There was no significant salinomycin $\times$ concentrate level interaction on plasma glucose concentration at any time after feeding. Dietary salinomycin did not influence plasma glucose concentration after feeding while the steers fed the high concentrate diet had higher plasma glucose levels compared to those of steers fed the low 
concentrate diet.

The main effect of dietary salinomycin and concentrate level on plasma insulin and insulin area are shown in Table 4. A significant interaction between dietary salinomycin and concentrate level on plasma insulin concentrations was observbed. Dietary salinomycin increased $(P<0.05)$ plasma insulin at $4-6 \mathrm{hrs}$ after feeding in the high concentrate diet, but did not do so in the low concentrate diet as shown in Table 5 . Higher plasma insulin was found $2 \mathrm{hrs}$ after feeding in the high concentrate diet-fed steers compared to the low concentrate diet-fed group. There were no signi-

Table 2. Main effects of dietary salinomycin and concentrate level on ruminal VFA proportion after feeding in fattening steers

\begin{tabular}{|c|c|c|c|c|c|c|}
\hline \multirow{2}{*}{ Treatment } & \multicolumn{6}{|c|}{ Time (hr) after feeding } \\
\hline & 0 & 1 & 2 & 3 & 4 & 6 \\
\hline Salinomycin & \multicolumn{6}{|c|}{ Acetate (\%) } \\
\hline 0 & 68.1 & 66.7 & 66.3 & 66.4 & 64.7 & 62.2 \\
\hline 200 & 66.9 & 65.4 & 62.7 & 64.2 & 62.1 & 59.7 \\
\hline \multicolumn{7}{|c|}{ Concentrate level } \\
\hline Low & 68.0 & 65.3 & 64.8 & 66.7 & 63.4 & 62.5 \\
\hline High & 66.9 & 66.7 & 64.3 & 63.9 & 63.3 & 59.3 \\
\hline Salinomycin & \multicolumn{6}{|c|}{ Propionate (96) } \\
\hline 0 & 22.0 & 23.9 & $24.3^{6}$ & $23.4^{d}$ & $23.8^{b}$ & $25.2^{6}$ \\
\hline 200 & 23.7 & 26.9 & $29.7^{\mathrm{a}}$ & $28.8^{c}$ & $30.9^{a}$ & $32.9^{\mathrm{a}}$ \\
\hline \multicolumn{7}{|c|}{ Concentrate level } \\
\hline Low & 21.7 & 25.7 & 26.5 & 25.1 & 27.6 & 27.5 \\
\hline High & 24.0 & 25.1 & 27.5 & 27.1 & 27.0 & 27.5 \\
\hline Salinomycin & \multicolumn{6}{|c|}{ Butyrate $(96)$} \\
\hline 0 & 9.9 & $9.5^{c}$ & $9.5^{\mathrm{a}}$ & $10.2^{\mathrm{a}}$ & $11.5^{\mathrm{a}}$ & $12.8^{\mathrm{a}}$ \\
\hline 200 & 9.7 & $7.8^{\mathrm{d}}$ & $7.7^{\mathrm{b}}$ & $2.1^{\mathrm{b}}$ & $7.1^{\mathrm{b}}$ & $7.5^{b}$ \\
\hline \multicolumn{7}{|c|}{ Concentrate level } \\
\hline Low & 10.3 & 9.0 & 8.8 & 8.2 & 9.0 & 10.0 \\
\hline High & 9.3 & 8.3 & 8.3 & 9.1 & 7.0 & 7.5 \\
\hline
\end{tabular}

Each value represents a mean of 16 observations. Mean values in the same time with unlike superscripts differ significantly ( $\mathrm{a}, \mathrm{b} \quad \mathrm{P}<0.05: \quad \mathrm{c}, \mathrm{d} \quad \mathrm{P}<0.10$ ).

1) See text.

Table 3. Main effects of dietary salinomycin and concentrate level on plasma glucose concentrations after feeding in fattening steers

\begin{tabular}{|c|c|c|c|c|c|c|}
\hline \multirow{2}{*}{ Treatment ${ }^{11}$} & \multicolumn{6}{|c|}{ Time (hr) after feeding } \\
\hline & 0 & 1 & 2 & 3 & 4 & 6 \\
\hline Salinomycin & \multicolumn{6}{|c|}{$(\mathrm{mg} / 100 \mathrm{ml})$} \\
\hline 0 & 73.4 & 67.3 & 67.6 & 69.8 & 70.2 & 71.5 \\
\hline 200 & 72.6 & 69.1 & 68.6 & 70.8 & 71.9 & 74.1 \\
\hline \multicolumn{7}{|c|}{ Concentrate level } \\
\hline Low & $69.3^{b}$ & $64.5^{b}$ & $64.3^{6}$ & $67.4^{\mathrm{b}}$ & $67.9^{b}$ & $69.9^{b}$ \\
\hline High & $76.7^{\mathrm{a}}$ & $71.8^{a}$ & $72.0^{\mathrm{a}}$ & $73.2^{\mathrm{a}}$ & $71.2^{\mathrm{a}}$ & $75.6^{2}$ \\
\hline
\end{tabular}

Each value represents a mean of 16 observations. Mean values in the same time with unlike superscripts differ significantly ( $a, b \quad \mathrm{P}<0.05)$

i) See text. 
Table 4. Main effects of dietary salinomycin and concentrate level on plasma insulin and insulin area after feeding in fattening steers

\begin{tabular}{|c|c|c|c|c|c|c|}
\hline \multirow{2}{*}{ Treatment 11} & \multicolumn{6}{|c|}{ Time (hr) after feeding } \\
\hline & 0 & 1 & 2 & 3 & 4 & 6 \\
\hline Salinomycin & \multicolumn{6}{|c|}{ Plasma insulin $(a \mathrm{U} / \mathrm{m} l)$} \\
\hline 0 & 24.8 & 31.4 & 29.7 & 30.4 & $26.7^{d}$ & $25.3^{\mathrm{b}}$ \\
\hline 200 & 24.3 & 31.4 & 35.6 & 32.8 & $33.6^{c}$ & $34.4^{\mathrm{a}}$ \\
\hline \multicolumn{7}{|c|}{ Concentrate level } \\
\hline Low & 24.4 & 29.1 & $28.8^{\mathrm{b}}$ & 29.9 & 27.5 & 27.1 \\
\hline High & 24.7 & 33.8 & $36.5^{\mathrm{a}}$ & 33.2 & 32.8 & 32.5 \\
\hline Salinomycin & \multicolumn{6}{|c|}{ Insulin area $(\mu \mathrm{U} / \mathrm{m} / / 6 \mathrm{hr})$} \\
\hline 0 & \multicolumn{6}{|c|}{$20.4^{\mathrm{b}}$} \\
\hline 200 & \multicolumn{6}{|c|}{$51.0^{\mathrm{a}}$} \\
\hline \multicolumn{7}{|c|}{ Concentrate level } \\
\hline Low & \multicolumn{6}{|c|}{$21.8^{d}$} \\
\hline High & \multicolumn{6}{|c|}{$49.6^{c}$} \\
\hline
\end{tabular}

Each value represents a mean of 16 observations. Mean values in the same time with unlike superscripts differ significantly ( $a, b \mathrm{P}<0.05 ; c, d \quad P<0.10$ ).

1) See text.

Table 5. Interaction of dietary salinomycin and concentrate level on plasma insulin concentrations at 4 and $6 \mathrm{hrs}$ after feeding in fattening steers.

\begin{tabular}{|c|c|c|}
\hline \multirow{2}{*}{ Treatment ${ }^{11}$} & \multicolumn{2}{|c|}{ Time (hr) after feeding } \\
\hline & 4 & 6 \\
\hline & \multicolumn{2}{|c|}{$(\mu \mathrm{U} / \mathrm{m} l)$} \\
\hline \multicolumn{3}{|l|}{ Low concentrate level } \\
\hline Salinomycin & 28.1 & 28.8 \\
\hline Salinomycin 200 & 27.0 & 25.5 \\
\hline \multicolumn{3}{|l|}{ High concentrate level } \\
\hline Salinomycin 0 & $25.4^{\mathrm{b}}$ & $21.9^{b}$ \\
\hline Salinomycin 200 & $40.2^{\mathrm{a}}$ & $43.2^{\mathrm{a}}$ \\
\hline
\end{tabular}

Each value represents a mean of 8 observations. Mean values in the same time with unlike superscripts differ significantly $(a, b \quad P<0.05)$.

1) See text.

ficant interaction between dietary salinomycin and concentrate level on the plasma insulin area. Dietary salinomycin increased $(P<0.05)$ the insulin area across concentrate levels in the diet. The high concentrate level also increased $(\mathrm{P}<0.10)$ the plasma insulin area across the dietary salinomycin treatment. It can be concluded from these observations that dietary salinomycin stimulated insulin secretory response to feeding across concentrate levels. However, the involvement of concentrate level in the diet in insulin secretory response to dietary salinomycin could not be explained in the present experiment.

ZINN, in an experiment where be observed the effect of salinomycin on beef cattle performance, reported that the digestible and estimated metabolizable energy content of the diet was not appreciably altered with the supplementation of dietary salinomycin and concluded that the role of salinomycin in improving feed conversion may be linked more directly to animal metabolism itself than to the effect of salinomycin on ruminal metabolism and site and to the extent of the digestion of the diet ${ }^{2)}$. The present experiment indicated that dietary salinomycin stimulated insulin secretory response to feeding. Although the involvement of increased insulin response to dietary salinomycin in beef cattle performance could not be elucidated at the present time, increased postprandial plasma insulin may partly account for the improved performance of beef cattle. The present results confirmed that dietary salinomycin stimulated insulin secretory response to feeding in fattening steers. However, the mechanism behind the phenomenon could not be 
explained in the present experiment.

\section{Acknowledgements}

This study was supported in part by the Kitasato University, School of Veterinary Medicine and Animal Sciences research grant (No. 6013).

\section{References}

1) Bergen. W.G. and D.B. Bates, J. Anim. Sci., 58 : 1465-1483. 1984.

2) BAgLeY, C.P., J.I. FEAZEL, D.G. MORRISON and D.M. LuCAS, J. Anim. Sci., $66: 792-797.1988$.

3) ZINN, R.A., J. Anim. Sci., $63: 1996-2004.1986$.
4) ZINN, R.A., J. Anim. Sci., 69: 2005-2012. 1986.

5) Nakashima, T., T. Masuno, R. Sakauchi and $S$. Hos HINO, Jpn. J. Zootech. Sci., 53 : 541-546. 1982.

6) Schelling, G.T., J. Anim. Sci., $58:$ 1518-1527. 1984.

7) Raun, A.P., C.O. Cooley, E.L. Potter, R.P. Rathmacher and L.F. Richardson, J. Anim. Sci., $43: 670-677.1976$.

8) Armstrona, J.D. and J.W. Spears, J. Anim. Sci., 66 : 1807-1817. 1988.

9) Prior, R.F. and S.B. SMIth, Federation Proc., 40: 2545-2549. 1982.

10) Sano, H., Y. Terashima and T. Senshu, Jpn. J. Zootech. Sci., $60: 70-77.1989$.

11) Richardson, L.F., A.P. Raun, E.L. Potter, C.o. COOLEY and R.P. Rothmacher, J. Anim. Sci., 43 : 657-664. 1976.

\title{
肥育牛の採食に伴うインスリン分泌反応に対する \\ サリノマイシン添加の影響
}

\author{
寺島福秋・畔柳 正・宮腰 裕 \\ 福田芳詔・近藤 洋 \\ 北里大学獣医畜産学部，十和田市 034
}

日本短角種の去勢牛 16 頭（約 10 力月齢，平均体重 $329 \mathrm{~kg}$ ）を用いて，採食に伴うインスリン分泌 反応に対するサリノマイシン添加の影響を検討した，肥育牛を 2 群に分け，濃厚飼料を体重の $0.6 \%$ お よび $1.8 \%$ を給与する区を設けた．それぞれの飼料区の 4 頭にサリノマイシンを給与 $(200 \mathrm{mg} /$ 頭/日) した。いずれの区でも粗飼料（アルファルファヘイキュウーブ）を自由採食させた．肥育期間を 10 力 月間とし，肥育開始後 240 および 360 日目に飼料給与後 6 時間にわたって血液およびルーメン液を経時 的に採取した。サリノマイシン添加は増体量に有意な影響を与えなかったか，飼料要求率を $14 \%$ 改善 した。サリノマイシン添加によってルーメン液のプロピオン酸濃度（モル\%）は增加し，酪酸農度は低 下した，酢酸濃度には影響を与えなかった．血墏グルコース濃度はサリノマイシン添加によって影響を 受けなかった。サリノマイシン添加は濃厚飼料の給与水準の高い区で給飼後 4-6 時間の血墏インスリン 濃度を增加させたが，濃厚飼料の給与水準の低い区では影響を与えなかった、給飼後 6 時間までのイン スリンエリアは，サリノマイシン添加之濃厚飼料の給与水準間に有意な交互作用はなく，サリノマイシ ン添加によって有意に增加した．これらの結果から，サリノマイシン添加は採食に伴うインスリンの分 泌反応を促進することが明らかになった。このインスリン分泌促進がサリノマイシンによる飼料要求率 改善の一要因となると推察された。

日畜会報， $61(3) ： 271-276 ， 1990$ 